Annals of Plant and Soil Research 23(1): 71-76 (2021)

https://doi.org/10.47815/apsr.2021.10032

\title{
Effect of foliar application of nitrogen and plant growth regulators on bearing, physico-chemical constituents and shelf-life of mango (Mangifera indica L.)
}

\author{
BIPUL KUMAR MANDALAND H.K. CHOURASIA ${ }^{1^{*}}$
}

Krishi Vigyan Kendra, Bihar Agricultural University, Sabour, Bhagalpur, Madhepura - 852 113, Bihar

Received: October, 2020; Revised accepted: December, 2020

\begin{abstract}
The experiment was carried out on ten-year-old Amarapali mango (Mangifera indica $L$ ) in randomized block design with seventeen treatments with three replications at BAU, Ranchi to study the effect of foliar application of nitrogen and plant growth regulators on bearing and physico-chemical constituent and self life of mango. Among the different treatments, application of 200ppm ethephon had most favourable effect in causing earliness in panicle emergence days (16.0 days), initiation of first flower (12.3 days) and days to initiation of fruit set (10.3 days) over control. Whereas application of 2000ppm triadimefon in combination with $2 \%$ urea increased intensity of flowering shoot to the extent of $88.5 \%$ in fruit plant. The maximum number of fruit set per panicle (44.7), fruit retention (12.1\%) and number of harvested fruit per tree (194.4) were observed with combined use of 100ppm SA and $2 \%$ urea as compared to control. The highest TSS $\left(25.1^{\circ}\right.$ Brix) and reducing sugar (3.0\%) content were registered under $100 \mathrm{ppm} \mathrm{GA}_{3}$, while the highest phenol $(2.84 \mathrm{mg} / 100 \mathrm{~g})$ was recorded from the fruits of the plants sprayed with 200ppm ethephon in combination with $2 \%$ urea. However, minimum (11.1\%) physiological loss in weight (PLW) was recorded in 100ppm SA along with $2 \%$ urea.
\end{abstract}

Keywords: Foliar application, plant growth regulators, physico-chemical constituents, mango

\section{INTRODUCTION}

Mango (Mangifera indica L.), an important fruit crop of India, is greatly relished for its succulence, exotic flavour and delicious taste. Amrapali, a cross between Neelum and Dushehari, has assumed significance in diversified fruit culture in north India. However, it has also low orchard efficiency and its cultivation is confronted with some serious problems. Among several reasons for low productivity, flower initiation and high incidence of fruit drop at initial stage of fruit development has been a problem of serious concern and various factors attributed to these maladies include depletion of nutrients, assimilate limitations (Prado, 2010) and hormonal imbalance (Kulkarni et al., 2017). For several fruit crop species, foliar nutrition has become routine in addition to, or as an alternative to, soil supply. (Bhamare et al., 2014; Sahoo et al., 2014).Similarly, in high yielding crops, foliar nutrient can be supplied to overcome transient situations where roots uptake is inadequate to meet the nutrient demand of the whole plant or specific organ such as fruit. Plant nutrient, particularly the level of $\mathrm{N}$ has more influence on the growth, yield and quality of mango than any other single plant nutrient. Foliar fertilization offers an opportunity to apply a significant portion of the total plant $\mathrm{N}$ requirement in a more efficient manner than traditional flood or ground application (Salama et al., 2016). The deficiency of nutrients and growth regulator also causes flower and fruit drop of varying degree at various stages (Tsomu and Patel, 2019). The use of plant growth regulators has assumed as an integral part of new and modern system of fruit production. Multifarious effects of auxins in control of flower and fruit drop as well as most striking and typical responses of gibbrellins on various growth and developmental phases of actively growing plant parts are apparent (Salama et al., 2016). Recently, salicylic acid $\left(\mathrm{C}_{7} \mathrm{H}_{6} \mathrm{O}_{3}\right)$ as aspirin and triadimefon (Triazole) have been accepted as a new plant growth regulator and found to generate a wide range of metabolic and physiological responses in plants there by affecting their growth and development (Amin et al., 2013; Koo et al., 2020). Salicylic acid, a phenolic compound induces flowering, increases flower life, retards senescence and increases cell metabolic rate. The sustained level of SA may be a pre requisite for the synthesis of auxin and/or cytokinin. It has also been established that triadimefon (Bayleton) possess a chlorophenyl which can protect plant against various stresses (Nair et al., 2012) delayed the

${ }^{7}$ Applied Microbiology and Plant Pathology Laboratory, University Department of Botany, T.M. Bhagalpur University, Bhagalpur-812 007, Bihar

*Correspondence E-mail : hkchourasia96@gmail.com 
onset of leaf senescence and increased antioxidant enzyme activities. The present study was undertaken to examine the effects of foliar application of urea, thio-urea and PGRs $\left(\mathrm{GA}_{3}\right.$, NAA, ethephon, SA and triadimefon) alone or incombination with urea on bearing, fruit production, physico-chemical compositions as well as shelf life of mango cv. Amrapali.

\section{MATERIALS AND METHODS}

The present investigation was conducted in two fruiting seasons at Horticulture garden, Birsa Agricultural University, Ranchi on uniform, well managed 10 years of Amrapali mango tree planted at a distance of $5 \times 5 \mathrm{~m}$. There were seventeen treatments viz., $2 \%$ urea, 1000 ppm thio-urea, 100 ppm GA 3 , 40 ppm NAA, 200 ppm ethephon, 100 and 200 ppm SA, 1000 and 2000 ppm triadimefon and all the PGRs incombination with urea along with control (water spray) each replicated thrice in RBD. These treatments were applied as spray in first week of December (before panicle initiation) and last week of March (after fruit set), using full tree as a unit of treatment. The orchard soil was sandy loam in texture with $\mathrm{pH} 5.4$, low in organic carbon $4.0 \mathrm{~g}$ $\mathrm{kg}^{-1}$ low in available nitrogen (245 kg ha'), medium in phosphorus $\left(30 \mathrm{~kg} \mathrm{ha}{ }^{-1}\right)$, potassium $\left(160 \mathrm{~kg} \mathrm{ha}^{-1}\right)$.Ten uniform shoots were selected randomly in each treatment and tagged. Date of panicle emergence and days to first flowering as well as days to fruit set was calculated in days after spraying of chemicals and these were recorded by visual observation through regular visiting the orchard. Total numbers of fruits per panicle on the tagged shoot initially and at the time of fruit maturity were counted and percent fruit retention was calculated on the basis of initial number of fruit set. Total number of fruits per tree were counted initially and at the time of harvest. Samples of 30 represented fruits were collected randomly from all sides of each plant and average fruit weight (g) was calculated whereas fruit size was measured using a vernier calliper. The fruit pulp, quality analysis including TSS, reducing sugar, acidity content, sugar/acid ratio, phenol were performed by following the method of Ranganna (1977).Mango fruit were harvested at commercial maturity from the orchard. Thereafter, fruit were transferred into bamboo baskets and kept at ambient condition (26-32 and $65-75 \% \mathrm{RH}$ ) for about 2 weeks in different lots. Fruits were assessed daily during shelf life evaluation for skin colour and firmness changes. Subjective visual skin colour ratings were; 1 . $100 \%$ green; $2.25 \%$ yellow; $3.50 \%$ yellow; $4.75 \%$ yellow and $5.100 \%$ yellow. Hand firmness rating was 1 . hand; 2 . firm; 3 . slightly soft; 4 . soft, and 5 . very soft. Data obtained for each year were pooled for each experiment and subjected to statistical analysis by following the method of variance described by Gomez and Gomez (1984).

\section{RESULTS AND DISCUSSION}

\section{Flowering}

The pooled data (Table 1)revealed that flowering characters were significantly influenced by the use of various plant growth regulators at different concentrations. Among different treatments, application of 200 ppm ethaphon had most favourable effect in causing earliness in panicle emergence (16.0 days), days to initiation of first flower (12.3 days) and days to initiation of fruit set (10.3 days) over control. It could be observed from the data that days to initiation of panicle took only 45.5 days after spraying, whereas days to initiation of first flowering and fruit set took 63.8 and 81.8 days, respectively as compared to control. Early differentiation of panicle and flower buds as well as shortage of duration required for flowering probably due to suppression of vegetative growth which might have created such condition in the shoot meristems conducive to early differentiation of flower primordial which in turn resulted early panicle emergence and flowering. In mango, exogenous application of ethephon inihibited vegetative growth of shoot and promoted flowering. Application of triadimefon (2000 ppm) in combination with urea (2\%) increased the intensity of flowering shoot $(88.5 \%)$ in fruit plant which was found almost equally effective with SA $100 \mathrm{ppm}$ mixed with urea $(88.5 \%)$ and triadimefon 2000 ppm (88.2\%) alone. There are evidences that $\mathrm{GA}_{3}$ plays an inhibitory role in mango flowering (Salamaet al.,2016) and triadimefon, a triazole compound has ability to reduce $\mathrm{GA}_{3}$ biosynthesis in shoot, resulted in profuse flowering. Similarly, SA also has greatest floric activity and enhances flowering in fruit plant. Salicylic acid (100 and 
$200 \mathrm{ppm})$ combined with urea $(2 \%)$ increased the panicle growth in terms of length and spread over all other treatments. Being potent plant growth regulator, SA plays an important role in regulating a number of plant physiological process including increase in cell metabolic rate and for the synthesis of auxin and/or cytokinin . Further, auxin increases the linear growth of stem which involves cell division, cell expansion and cell differentiation (Kulkarni et al., 2017) hence resulted into increase in panicle growth. Besides, SA nitrogen as consequences of urea also enhanced carbohydrate reserve and auxin synthesis which in turn played a decisive role in this regard.

Table 1: Effect of chemicals on flowering characters of Amrapali mango

\begin{tabular}{|l|c|c|c|c|c|c|}
\hline \multicolumn{1}{|c|}{ Treatments } & $\begin{array}{c}\text { Days to } \\
\text { panicle } \\
\text { emergence }\end{array}$ & $\begin{array}{c}\text { Day to first } \\
\text { flowerings }\end{array}$ & $\begin{array}{c}\text { Days to } \\
\text { fruit set }\end{array}$ & $\begin{array}{c}\text { \% of } \\
\text { flowering } \\
\text { shoot }\end{array}$ & $\begin{array}{c}\text { Panicle } \\
\text { length } \\
\text { (cm) }\end{array}$ & $\begin{array}{c}\text { Panicle } \\
\text { spread } \\
\text { (cm) }\end{array}$ \\
\hline Urea-2\% & 53.7 & 69.8 & 95.0 & $55.0(48.0)$ & 28.5 & 10.0 \\
Thiourea-1000ppm & 52.2 & 68.8 & 91.3 & $61.4(51.9)$ & 29.6 & 10.4 \\
GA $_{3}$-100ppm & 52.7 & 68.3 & 93.5 & $58.2(50.0)$ & 29.6 & 10.2 \\
NAA-40ppm & 56.0 & 70.6 & 93.5 & $72.7(58.6)$ & 29.1 & 9.9 \\
Ethephon 200ppm & 45.5 & 63.8 & 87.8 & $82.8(65.4)$ & 30.8 & 10.9 \\
Salicylic Acid-100ppm & 51.0 & 69.8 & 92.1 & $84.8(67.1)$ & 32.4 & 12.4 \\
Salicylic Acid-200ppm & 48.8 & 68.3 & 90.3 & $86.1(68.1)$ & 32.0 & 11.8 \\
Triadimefon- 1000ppm & 51.7 & 70.0 & 91.5 & $85.0(67.8)$ & 32.3 & 11.5 \\
Triadimefon- 2000ppm & 47.2 & 67.3 & 90.8 & $88.2(73.4)$ & 32.7 & 11.9 \\
GA $100 p p m$ + Urea-2\% & 56.0 & 69.7 & 94.5 & $68.5(56.0)$ & 29.8 & 10.4 \\
NAA40ppm + Urea-2\% & 57.7 & 70.3 & 94.3 & $72.2(58.4)$ & 29.7 & 10.3 \\
Ethephon 200ppm + Urea-2\% & 48.5 & 67.3 & 91.0 & $82.0(64.9)$ & 30.6 & 11.0 \\
SA 100 ppm + Urea-2\% & 51.5 & 69.1 & 92.0 & $88.5(70.2)$ & 33.1 & 12.3 \\
SA 200 ppm + Urea-2\% & 50.0 & 69.7 & 90.6 & $84.8(70.6)$ & 33.4 & 12.0 \\
Tri 1000 ppm + Urea-2\% & 50.0 & 71.0 & 92.3 & $88.5(66.2)$ & 31.5 & 11.3 \\
Tri 2000 ppm + Urea-2\% & 53.7 & 72.2 & 92.8 & $88.5(66.5)$ & 31.6 & 11.2 \\
Control Water spray & 61.5 & 76.1 & 98.1 & $48.6(38.1)$ & 23.8 & 8.3 \\
SEM ( ( $)$ & 1.1 & 1.7 & 1.95 & 3.1 & 1.0 & 0.4 \\
CD (5\%) & 3.3 & 4.8 & 5.5 & 9.4 & 2.9 & 1.3 \\
CV (\%) & 5.8 & 5.6 & 6.0 & 7.2 & 8.8 & 11.7 \\
\hline
\end{tabular}

\section{Fruiting}

The perusal of data (Table 2) indicated that the spray of chemical treatments significantly increased the number of fruit set per panicle and fruit retention percentage over control. The mean maximum number of fruit set per panicle (44.7) and fruit retention (12.1\%) were recorded at SA $100 \mathrm{ppm}$ combined with urea $(2 \%)$ spray as compared to mean minimum at control i.e. number of fruit set percentage (24.4) and fruit retention of $5.8 \%$. The developing fruits need auxin in higher quantity and fruit drops occur when auxin levels goes down. By exogenous application of SA and urea, the deficiency of the auxins was met and ultimately fruit drop checked which resulted into more fruit retention. As both SA and urea are capable of synthesizing auxin as suggested by several workers earlier. The obtained results are in line with those reported by Nicholas and
Embree (2004) on apple tree. The maximum fruit size $(11.6 \mathrm{~cm}$ and $7.7 \mathrm{~cm})$ was obtained with $\mathrm{GA}_{3} 100 \mathrm{ppm}$. Improvement in fruit size following application of chemicals was probably due to faster rate of fruit growth owing to rapid cell division and cell enlargement. The exogenous application of $\mathrm{GA}_{3}$ might have increased the indigenous level of growth promoting substances which in turn stimulated cell division and elongation consequently rate of growth and development of fruit was enhanced, resulted in larger fruit size. The present result are in corroboration with observations made by Rohit (2014) in Langra mango with $\mathrm{GA}_{3}$ application. Yield attributing characters in mango studied in terms of number of fruits per plant showed that the maximum number of harvested fruits per tree (194.4) was obtained with SA 100ppm + urea (2\%) followed by SA $200 \mathrm{ppm}+(2 \%)$ urea(177.0). The increase in number of fruits harvested per tree is due to higher fruit set and 
fruit retention percentage/panicle. The lowest number of fruit per tree (40.2) was obtained in control. Higher yield with SA treatment was reported by Karlidaget al. (2009) on strawberry.

Table 2: Effect of chemicals on fruiting characters of Amrapali mango

\begin{tabular}{l|c|c|c|c|c|c|c|}
\hline \multicolumn{1}{|c|}{ Treatments } & $\begin{array}{c}\text { Fruit set } \\
\text { /panicle }\end{array}$ & $\begin{array}{c}\text { Fruit } \\
\text { retention (\%) }\end{array}$ & $\begin{array}{c}\text { Fruit } \\
\text { length }(\mathrm{cm})\end{array}$ & $\begin{array}{c}\text { Fruit breadth } \\
(\mathrm{cm})\end{array}$ & $\begin{array}{c}\text { Fruits / } \\
\text { tree }\end{array}$ & $\begin{array}{c}\text { Pulp } \\
(\%)\end{array}$ & Stone (\%) \\
\hline Urea-2\% & 29.1 & $7.2(15.7)$ & 10.3 & 6.8 & 59.4 & 59.4 & $13.3(20.9)$ \\
Thiourea-1000ppm & 33.3 & $7.8(16.1)$ & 10.7 & 7.2 & 75.8 & 75.8 & $15.4(23.1)$ \\
GA $_{3}-100 p p m$ & 31.4 & $8.2(16.6)$ & 11.6 & 7.7 & 87.9 & 87.9 & $12.4(20.6)$ \\
NAA-40ppm & 32.7 & $6.9(15.2)$ & 10.2 & 6.9 & 76.3 & 76.3 & $16.6(23.9)$ \\
Ethephon 200ppm & 38. & $8.8(17.1)$ & 11.1 & 7.4 & 119.7 & 119.7 & $15.0(23.1)$ \\
Salicylic Acid-100ppm & 38.9 & $10.7(19.0)$ & 10.8 & 7.3 & 158.9 & 158.9 & $17.8(24.9)$ \\
Salicylic Acid-200ppm & 42.6 & $10.4(18.8)$ & 10.2 & 7.2 & 153.6 & 153.6 & $16.0(23.8)$ \\
Triadimefon- 1000ppm & 41.3 & $9.7(18.4)$ & 10.6 & 6.9 & 160.0 & 160.0 & $15.9(23.7)$ \\
Triadimefon- 2000ppm & 42.8 & $11.2(18.9)$ & 10.4 & 6.9 & 153.9 & 153.9 & $15.8(23.7)$ \\
GA $A_{3}$ 100ppm + Urea-2\% & 32.8 & $7.8(16.8)$ & 11.3 & 7.5 & 99.5 & 99.5 & $14.9(22.6)$ \\
NAA40ppm + Urea-2\% & 37.2 & $7.1(15.9)$ & 10.7 & 6.9 & 99.2 & 99.2 & $13.6(21.6)$ \\
Ethephon 200ppm + Urea-2\% & 34.3 & $9.1(17.6)$ & 11.5 & 7.2 & 113.8 & 113.8 & $13.2(21.3)$ \\
SA 100 ppm + Urea-2\% & 44.7 & $12.1(20.1)$ & 9.7 & 6.6 & 194.4 & 194.4 & $16.1(23.6)$ \\
SA 200 ppm + Urea-2\% & 39.8 & $11.4(21.2)$ & 9.8 & 6.7 & 177.0 & 177.0 & $11.1(19.8)$ \\
Tri 1000 ppm + Urea-2\% & 41.2 & $9.8(18.2)$ & 9.8 & 6.7 & 155.1 & 155.1 & $17.5(24.7)$ \\
Tri 2000 ppm + Urea-2\% & 38.2 & $10.0(19.6)$ & 9.9 & 6.7 & 152.9 & 152.9 & $14.4(22.2)$ \\
Control Water spray & 24. & $5.8(14.5)$ & 8.5 & 6.1 & 40.2 & 40.2 & $21.9(28.0)$ \\
SEM ( \pm (5) & 1.0 & 0.7 & 0.4 & 0.4 & 5.8 & 5.8 & 1.52 \\
CD (5\%) & 2.8 & 2.3 & 1.3 & 1.2 & 16.4 & 16.4 & NS \\
CV (\%) & 7.0 & 6.0 & 10.1 & 16.7 & 12.5 & 12.5 & 9.36 \\
\hline
\end{tabular}

Maximum pulp recovery of $71.4 \%$ and minimum stone percentage (11.1) were recorded from the fruits treated with $200 \mathrm{ppm} \mathrm{SA} \mathrm{+} \mathrm{urea}$ (2\%) followed by $\mathrm{GA}_{3} 100 \mathrm{ppm}(71.2 \%)$ and minimum in control $(60.6 \%)$. The results are in close proximity with the findings of Bhowmick and Banik (2006) in Langra mango with $\mathrm{GA}_{3}$ application. Increase in pulp percentage due to SA might be due to its participation in regulation of several physiological processes related to production of photosynthates, total drymatter and also with the increase in cell size of mesocarp. However, role of $\mathrm{GA}_{3}$ in this regard may be due to its role in increasing cell elongation and increase in sink demand through enhancement of phloem unloading or/and metabolism of carbon assimilates of fruits.

The data (Table 3 ) clearly indicated that TSS was highest $\left(25.1{ }^{0}\right.$ Brix $)$ in the fruits sprayed with $100 \mathrm{ppm} \mathrm{GA}_{3}$ followed by triadimefon $2000 p p m+2 \%$ urea $\left(24.3^{\circ}\right.$ Brix $)$ and they were statistically at par. Like TSS, reducing sugar content was also maximum under 100ppm $\mathrm{GA}_{3}(3.0 \%)$. Total soluble solid contents was recorded lowest $\left(20.2^{\circ} \mathrm{Brix}\right)$ in the fruits from control plants, whereas lowest reducing sugar $(1.7 \%)$ in $200 \mathrm{ppm}$ SA. According to Ghosh (2016) increase in TSS caused by 100ppm
$\mathrm{GA}_{3}$ might be due to higher rates of transpiration and respiration, and increases in physiological loss in weight and breakdown of complex polymers into simple substances by hydrolytic enzymes of fruits. Similar findings have been reported in mango cv. Alphanso fruits by Dalvi et al. (2009). The lowest acidity percentage (0.2) and highest sugar acid ratio (52.5) were measured from the fruits in the plants sprayed with 40ppm NAA followed by 200ppm SA (46.3) which was also statistically at par. The results also agree to those of Kulkarni et al. (2017) in mango CV. Kesha. The increase in this ratio was directly due to increase in sugar content and decrease in acidity of fruits. Further, it was observed that highest phenol $(2.84 \mathrm{mg} / 100 \mathrm{gm})$ was recorded from the fruits of the plants sprayed with ethephon $200 \mathrm{ppm}+$ urea $(2 \%)$ and found statistically comparable with 2000 ppm triadimefon $+2 \%$ urea $(2.6 \mathrm{mg} / 100 \mathrm{~g})$, whereas lowest phenol content $(1.2 \mathrm{mg} / 100 \mathrm{~g})$ was registered under $100 \mathrm{ppm}$ SA. The increased phenol content due to triadimefon might be due to its increased antioxidant enzyme activity (Ragupathiet al., 2008). The results agreed to some extent with Jaleel et al. (2008) with triazole compound in Catharanthus roseus. 
Table 3 Effect of chemicals on physico-chemical characters of Amrapali mango

\begin{tabular}{|c|c|c|c|c|c|c|c|}
\hline Treatments & $\begin{array}{c}\text { TSS } \\
\left({ }^{\circ} \text { Brix }\right)\end{array}$ & $\begin{array}{l}\text { Reducing } \\
\text { sugar (\%) }\end{array}$ & $\begin{array}{c}\text { Acidity } \\
(\%)\end{array}$ & $\begin{array}{l}\text { Total } \\
\text { Sugar/ } \\
\text { Acid }\end{array}$ & $\begin{array}{c}\text { Phenol } \\
\text { (mg/100g) }\end{array}$ & PLW (\%) & $\begin{array}{c}\text { Net } \\
\text { Profit/Plant } \\
\text { (Rs.) }\end{array}$ \\
\hline Urea-2\% & 22.1 & 2.7 & 0.3 & 29.6 & 1.7 & $14.5(22.4)$ & 105.8 \\
\hline Thiourea-1000ppm & 21.1 & 2.6 & 0.3 & 23.1 & 1.5 & $13.1(21.2)$ & 216.6 \\
\hline $\mathrm{GA}_{3}-100 \mathrm{ppm}$ & 25.1 & 3.0 & 0.2 & 34.1 & 2.5 & $13.9(21.8)$ & 103.0 \\
\hline NAA-40ppm & 22.6 & 2.5 & 0.2 & 52.5 & 1.6 & $13.1(21.2)$ & 206.7 \\
\hline Ethephon 200ppm & 21.1 & 2.5 & 0.2 & 30.6 & 1.5 & $13.4(21.5)$ & 279.0 \\
\hline Salicylic Acid-100ppm & 22.5 & 1.8 & 0.2 & 41.2 & 1.2 & $12.2(20.4)$ & 365.8 \\
\hline Salicylic Acid-200ppm & 20.5 & 1.7 & 0.1 & 46.3 & 2.1 & $12.6(20.7)$ & 364.8 \\
\hline Triadimefon- $1000 \mathrm{ppm}$ & 22.6 & 2.1 & 0.2 & 32.1 & 2.1 & $12.2(20.4)$ & 246.8 \\
\hline Triadimefon- 2000ppm & 22.1 & 1.9 & 0.3 & 41.2 & 1.7 & $13.8(21.8)$ & 138.3 \\
\hline $\mathrm{GA}_{3} 100 \mathrm{ppm}+$ Urea-2\% & 23.6 & 2.5 & 0.3 & 25.1 & 2.1 & $15.0(22.8)$ & 42.6 \\
\hline NAA40ppm + Urea-2\% & 19.9 & 1.5 & 0.3 & 24.0 & 2.1 & $14.5(22.4)$ & 169.5 \\
\hline Ethephon 200ppm + Urea-2\% & 22.8 & 2.8 & 0.2 & 29.6 & 2.8 & $14.6(22.4)$ & 199.0 \\
\hline SA 100 ppm + Urea-2\% & 23.2 & 2.2 & 0.3 & 33.1 & 2.4 & $11.1(19.4)$ & 343.9 \\
\hline SA 200 ppm + Urea-2\% & 21.9 & 2.4 & 0.2 & 40.1 & 1.9 & $13.3(21.4)$ & 353.4 \\
\hline Tri 1000 ppm + Urea-2\% & 23.7 & 2.4 & 0.3 & 23.1 & 1.5 & $11.8(20.0)$ & 158.2 \\
\hline Tri 2000 ppm + Urea-2\% & 24.3 & 2.9 & 0.3 & 30.0 & 2.6 & $14.8(22.6)$ & 46.2 \\
\hline Control Water spray & 20.3 & 2.0 & 0.1 & 44.6 & 1.7 & $19.5(26.2)$ & 147.6 \\
\hline SEM ( \pm$)$ & 0.4 & 0.0 & 0.007 & 2.8 & 0.4 & 0.9 & \\
\hline $\mathrm{CD}(5 \%)$ & 1.3 & 0.1 & 0.02 & 8.0 & 0.1 & 2.7 & \\
\hline CV $(\%)$ & 4.7 & 6.7 & 6.8 & 22.5 & 5.8 & 5.9 & \\
\hline
\end{tabular}

The perusal of the data (Table 3 ) clearly indicated that on the last day of observation $\left(13^{\text {th }}\right.$ day storage) minimum physiological loss in weight $(11.1 \%)$ in SA $100 \mathrm{ppm}+2 \%$ urea and in $1000 \mathrm{ppm}$ triadimefon $+2 \%$ urea $(11.8 \%)$ were observed. However, maximum PLW 19.5\% were noted in control (water sprayed). Decrease in PLW percent due to salicylic acid treatment might be due to inhibition of ethylene

\section{REFRENCES}

Amin, A.A., Abdelkadar. A.A., Shalaby, M.A.F., Gharib, F.A.E., Rashad, E.S.M. and Silva, J.A.T. (2013) Physiological effects of salicylic acid and thiourea on growth and productivity of maize plants in sandy soil.Communications in Soil Science and Plant Analysis 44 : 1141-1155.

Bhamare, S.P., Patel, H.C., and Rajput, S.G. (2014) Effect of foliar spray of PGPR's on fruit drop in mango cv Mallika. Bioinfolet $11: 570-571$.

Bhowmick, N. and Banik, B.C. (2006) Influence of NAA and $\mathrm{GA}_{3}$ on fruit retention, yield and physic-chemical properties of mango cv. Amrapali in West Bengal.The Horticulture Journal 19 : 158. biosynthesis. An ethylene suppression role might have extended the shelf life (green life) of fruit. The highest average net profit per plant was obtained in treatment SA $100 \mathrm{ppm}$ followed by SA 200 ppm and 200 ppm SA + urea $2 \%$ and their corresponding amounts were Rs. 365.8/plant, Rs. 364.8/plant and Rs. 353.4/plant, respectively.

Dalvi, M.B., Pushpa, D.P. and Raut, S.P. (2009) Pre-and post-harvest losses in fruits of mango (Mangifera indica).Journal of Mycology and Plant Pathology 39 : 385390.

Ghosh, S.N. (2016) Effect of plant growth regulators on fruit retention and physicochemical properties of mango cv. Amrapali grown in laterite soil at close spacing. Journal of Crop and Weed 12 : 83-85.

Gomez, K.A. and Gomez, A.A. (1984) Statistical Procedures for Agricultural Research, II Ed. John Willey and Sons Publication, New York, 680 p.

Jaleel, C.A., Gopi, R. and Panneerselvam, R. (2008) Growth and photosynthetic 
pigments reponses of two varieties of Catharanthus roseus to triadimefon treatment. Comptes Rendus Biologies $331: 272-276$.

Karlidag, H., Yieldrim E. and Turan M.(2009) Exogenous applications of S.A affect quality and yield of strawberry grown under antifrost heated green house conditions. Journal Plant Nutrition and Soil Science 172 : 270.

Koo, Y.M., Heo, A.Y. and Choi, H.W. (2020) Salicylic acid as a safe plant protector and growth regulator.Plant Pathology Journal $36: 1-10$.

Kulkarni, S.S., Patil, S.S. and Magar, S.D. (2017) Effect of plant growth regulators on yield and quality of mango (Mangifera indica L.) CV Kesha. Journal of Pharmacognosy and Phytochemistry 6 : 2309-2313.

Nair, D., Ragupathi, G., Mohankumar, $M$ and Kavina, J. (2012) Effect of triadimefon : A triazole fungicide on oxidative stress defense system and eugenol content in Ocimum tenuiflorum L. Acta Physiologiae Plantarum 34 : 599-605.

Prado, R.M. (2010) Phosphorus effects in the nutrition and growth of developing mango plants. Journal of Plant Nutrition 33 : 2041-2049.

Ragupathi, G., Panneerselavam, R., Javeel, C.A. and Mannivannan, P. (2008) Exogenous application of triadimefon affects the antioxidant defense system of Withania somnifera. Pesticide Biochemistry and Physiology 91: 170174.
Ranganna, S. (1977) Handbook of analysis and quality control for fruit and vegetable products. McGraw-Hill Publishing Co Ltd., New Delhi, pp. 80-82.

Rohit, S. (2014) Effect of GA3 and urea spray of flowering, fruit retention and fruit quality of mango cv Langra. Ph.D. dissertation, Jawaharlal Nehru Krishi Vishwavidyalay, Jabalpur

Sahoo, A.K., Behera, B.S., Mishra, N. and Mohanty, A. (2014) Effect of foliar feeding of growth promoting substances on vegetative growth of pre-bearing mango plantation - A review. Journal of Plant and Pest Science 1 : 96-100.

Salama, A.S.M., Abdelhameed, A.A. and Elgammal, O.H.M. (2016) Effect of gibberellins and urea foliar spray on blooming, fruiting and fruit quality of mango trees cv Fagri Kalan. J Agriculture Veterinary Science 9 : 9-19. Tagliavini, M. and Toselli, M. (2005) Foliar nutrition of plants. In: Encyclopedia of soils in the Environment (Hillel, D. ed). Elsevier Ltd., Oxford, U.K. Vol. 2, 53.

Singh, D. and Manivannan, S.(2009) Genetic resources of horticultural crops. International Book Distributing Co. Lucknow, pp. 61.

Tsomu, T. and Patel, H.C. (2019) Effect of foliar spray of plant growth regulators and micronutrients on yield and physical parameters of mango cv Mallika. International Journal of Chemical Studies 7: 4968-4973. 